\title{
Advanced Construction Materials for High Temperature Steam PEM Electrolysers
}

\author{
Aleksey Nikiforov, Erik Christensen, Irina Petrushina, Jens Oluf Jensen \\ and Niels J. Bjerrum
}

Additional information is available at the end of the chapter

http://dx.doi.org/10.5772/51928

\section{Introduction}

\subsection{Principles of polymer electrolyte membrane (PEM) water electrolysis}

There are main 3 types of electrolyzers: alkaline, acidic and solid oxide electrolyzer cell (SOEC). This chapter will be concentrated on acidic electrolyzers, where reactions follow the pathes (reactions 1,2).

$$
\begin{gathered}
\text { cathode }: 2 \mathrm{H}^{+}+2 \mathrm{e}^{-} \rightarrow \mathrm{H}_{2} \\
\text { anode }: \mathrm{H}_{2} \mathrm{O} \rightarrow \frac{1}{2} \mathrm{O}_{2}+2 \mathrm{H}^{+}+2 \mathrm{e}^{-}
\end{gathered}
$$

The efficiency of water splitting by electrolysis is rather low for conventional electrolyzers and there is hence a large potential for improvement.

The modern acidic electrolysers use polymeric proton conducting membranes, e.g. Nafion ${ }^{\circledR}$ or PBI, doped with phosphoric acid.

One of the potential advantages of PEM cells over more abundant alkaline electrolyzers is that they were shown to be reversible [21,31,69]. The type of an electrochemical cell working both as a fuel cell and a water electrolyzer is called a unitized regenerative fuel cells (URFC) [13, 38, $67,70]$. These devices produce hydrogen from water in the electrolysis mode, while electricity can be inversely produced in the fuel cell mode. This mode of working is beneficial when the lack of electricity changes with the excess energy available (periods of low consumption) [61].

PEM water electrolysis technology is frequently presented in literature as a potentially very effective alternative to more conventional alkaline water electrolysis [43, 46, 47]. Among advantages are higher production rates and energy efficiency [60]. In a future "hydrogen society" this method is envisioned as a part of the "energy cycle", where hydrogen acts as an energy carrier. In this cycle, electricity from renewable energy sources is used in electrolysis for electrochemical splitting of water [26]. PEM cells usually use perfluorinated ion-exchange membranes as an electrolyte (known under the trademark Nafion ${ }^{\circledR}$ ). 
In a PEM cell the electrolyte is a solid ion-exchange membrane, which does not involve compulsory circulation of electrolyte through it. Different types of ionic membranes will be discussed in Section 2. The electrodes are usually directly sprayed or pressed on the opposite sites of the solid polymer electrolyte (SPE), thus being the origin of a membrane electrode assembly (MEA) $[1,5,67,78]$. Also, electrodes can be sprayed on the gas diffusion layer (GDL), and then put together leaving the SPE between them [56, 79]. A PEM electrolyzer stack consists of a combination of several cells (as many as 100), electrically connected in series [54]. The cells are separated from each other by a metal plate (also called a bipolar plate), which serves both as a current collector and as an interconnect to the next cell in the stack. Flows of evolved hydrogen and oxygen are usually swept out through the bipolar plate by water flow and further separated from it outside the cell.

Several commercial types of PEM electrolyzers are available today on the market [27-29]. Some units have power up to $44 \mathrm{~kW}$ and claimed lifetime up to 40,000 hours. Still, the main drawbacks of such systems are the price of materials and complex system components, which ensures save and reliable function.

\subsection{High temperature PEM electrolysis. Advantages and drawbacks}

At temperatures above the boiling point of water, the energy efficiency of water splitting can be significantly improved because of decreased thermodynamic energy requirements, which is one of the major advantages of these systems.

Since water electrolysis becomes increasingly heat consuming with temperature (Figure 1), larger portion of the total energy demand can be provided as heat at elevated temperatures. This provides an opportunity to utilize the Joule heat, that is inevitably produced due to the passage of electrical current through the cell. In this way, the overall electricity consumption and, thereby, the $\mathrm{H}_{2}$ production price can be reduced.

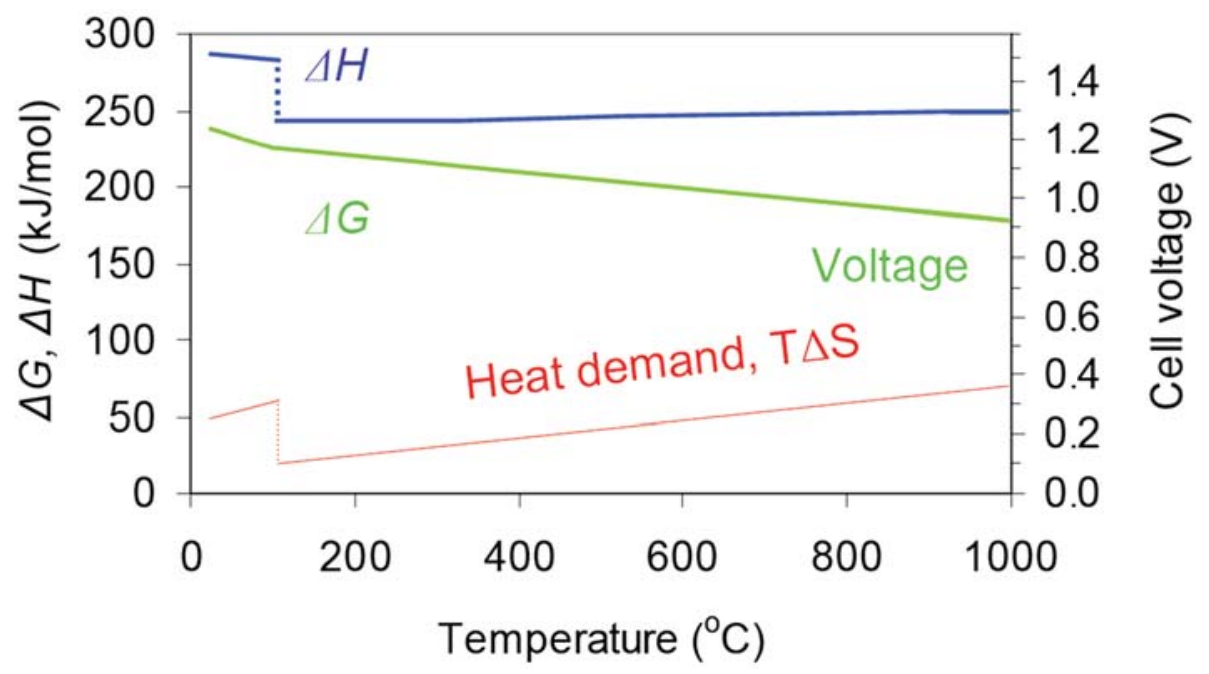

Figure 1. The theoretical cell voltage as a function of temperature [35] 
Since the reaction of water splitting is not spontaneous and the Gibbs free energy is positive, a positive change of a factor $T \cdot \Delta S^{\ominus}$ in the equation 3 means less energy needs to be applied. As the reaction has a positive entropy, the equilibrium will be displaced towards the products for high temperatures. The term $T \cdot \Delta S^{\ominus}$ increases with increasing temperature, thus increasing the contribution of thermal energy to the total needs for the water splitting reaction [66]. Therefore, the part of heat, which can be used for the reaction is higher, meaning that the production costs of hydrogen are decreased [58]. It was noticed much earlier that econonomic reasons force to move towards high temperature electrolysis $\left(120-150{ }^{\circ} \mathrm{C}\right)$ [73].

$$
\begin{aligned}
\Delta G^{\ominus} & =\Delta H^{\ominus}-T \cdot \Delta S^{\ominus} \\
\Delta G^{\ominus} & =-n F \Delta E^{\ominus} \\
\Delta S^{\ominus}>0 & \rightarrow \frac{d G^{\ominus}}{d T}<0 \\
\frac{d \Delta E^{\ominus}}{d T} & =-\frac{d \Delta G^{\ominus}}{d T}>0
\end{aligned}
$$

According to the Arrhenius' equation 4, the kinetics of the electrode reactions is enhanced at elevated temperatures. It is associated with lower overpotentials at the electrodes, giving higher efficiency for electrolysis.

$$
k_{f}=E_{A_{f}} \exp \left(\frac{\Delta G_{c}^{\ddagger}}{R T}\right)
$$

Another positive opportunity provided while operating at temperatures above $100{ }^{\circ} \mathrm{C}$ is that water is not in a liquid phase (at ambient pressure) and this fact significantly simplifies water/gas management. In this case all the reactant/product flows are in a steam phase and the transport of them is easier, which provides simplified stack construction and operation [44].

The heat management is also easier for high temperature systems, as the heat flow out of the system is proportional to the temperature gradient between the cell and the ambient. This means that cooling is more effective in elevated-temperature systems, as there are less efficiency losses associated with the forced cooling of the cell [36].

Another benefit of high temperature systems is attributed to the decreased sensibility of catalysts towards poisoning by adsorption of inhibiting agents. This effect is acknowledged to be a considerable advantage of high temperature PEM fuel cells (HTPEMFCs) [44]. The inhibition mechanism usually involves chemisorption of species on the catalyst surface, covering and screening it from interacting with the reactants. This adsorption is weaker at higher temperatures, giving higher tolerance to impurities [16].

However, with increasing temperature, the probability and rate of side processes, such as dissolution of the electrodes and components corrosion, is higher. This decreases the lifetime of the whole system and increases demands to all materials used with respect to corrosion and thermal stability $[19,46]$. The corrosion issue for construction materials in such cells will be addressed in the following Section 3. 


\section{Acidic electrolytes and polymer electrolyte membranes technology}

The electrolyte is one of the main components of any type of electrolyzer. The importance of the electrolyte is emphasized by the fact that the type of electrolyzer, as well as of fuel cell, is named after the type of electrolyte used. In the classical view it is traditionally a solution of acid, base or water soluble salt in the water. When added, those dissociate into ions in the solution, which increases conductivity of pure water.

The acidic water electrolysis traditionally uses sulphuric or phosphoric acid as they are stable within the potential window of water. The acid increases the conductivity of water through the donating protons.

The polymer electrolyte membrane (PEM) is a membrane which acts as a proton conductor in electrolyzer cell. Usually, the ionic membrane consists of a solid polytetrafluoroethylene (PTFE) backbone, which is chemically altered and contains sulfonic ionic functional groups thus the pendant side chains terminated with $-\mathrm{SO}^{3-}$. The acid dissociates and release protons by the following mechanism (5):

$$
\mathrm{SO}_{3} \mathrm{H}^{-}=>\mathrm{SO}_{3}^{-}+\mathrm{H}^{+}
$$

The membranes of this type allow water molecules to penetrate into its structure, while remaining not permeable to molecular $\mathrm{H}_{2}$ and $\mathrm{O}_{2}$. The sulfonic groups are responsible for the transfer of protons during electrolysis, where a hydrated proton $\mathrm{H}_{3} \mathrm{O}^{+}$can freely move within the polymer matrix, while a sulfonate ion $\mathrm{SO}^{3-}$ is fixed to the side chain of polymer. When electric current flows across the membrane, the hydrated protons are attracted to the cathode, where they are combined into hydrogen. Nafion ${ }^{\circledR}$ is the most known trademark among ionic membranes and is patented by Du Pont Company in 1966 [15]. A typical membrane has a thickness in the range of 50-100 $\mu$ meters and this type of membrane is commonly used as an electrolyte for conventional PEM water electrolyzers [23, 56, 79]. These membranes have excellent chemical stability, high ionic conductivity and excellent mechanical strength [56]. Water electrolysis using Nafion ${ }^{\circledR}$ as an electrolyte is a promising technology for large-scale hydrogen production $[8,75]$.

The conductivity of such membranes decreases significantly at temperatures above 80 ${ }^{\circ} \mathrm{C}$, which is associated with the ion of water content [42, 45]. Sufficient efficiency is achieved using Poly[2,2'-(m-phenylene)-5,5'-bibenzimidazole (PBI) membranes doped with phosphoric acid in PEM fuel cells at temperatures up to $200{ }^{\circ} \mathrm{C}$ under ambient pressure [36, 44, 45]. The structure of PBI is shown in Figure 2. Doped PBI membranes are a potential electrolyte for use in PEM steam electrolyzer systems. The ionic conductivity of membranes increases with temperature [45], which means the higher the working temperature is, the lower ohmic losses through electrolyte are. In spite of that, the conditions of extremely low $\mathrm{pH}$ combined with high overpotentials at the anodic compartment of the oxygen evolution electrode (OEE) impose serious limitations on materials which can be used in these cells.

In the laboratory conditions commonly $0.5 \mathrm{M}$ sulphuric acid is used for screening electrode materials in a 3-electrode electrochemical cells, simulating conditions of the Nafion ${ }^{\circledR}$-based systems, which work at temperatures below $100^{\circ} \mathrm{C}$ [51, 52]. Since high temperature PEM cells are working at temperatures around $150{ }^{\circ} \mathrm{C}, \mathrm{H}_{2} \mathrm{SO}_{4}$ cannot be used to simulate conditions in the 3-electrode cell, even at high concentration. Instead, concentrated $\mathrm{H}_{3} \mathrm{PO}_{4}$ can ben used, which permits to work at temperatures as high as $150-160{ }^{\circ} \mathrm{C}$, depending on the composition [14]. 


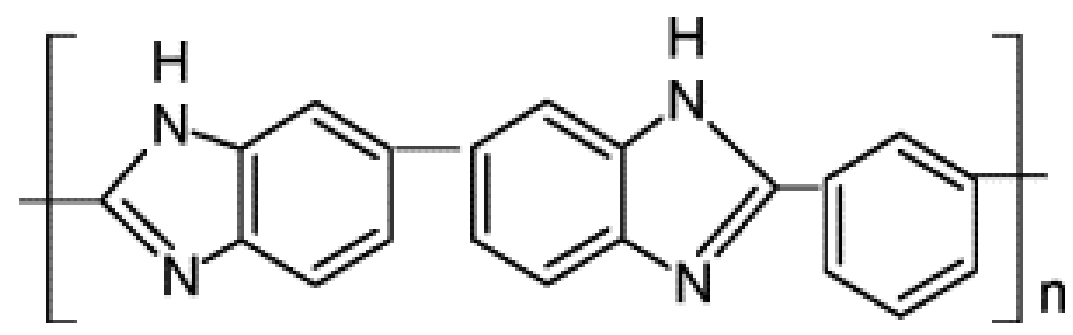

Figure 2. General structure of Poly[2,2'-(m-phenylene)-5,5'-bibenzimidazole (PBI) [45].

However, it was noticed by Appleby and Van Drunen that the Tafel slopes for noble electrocatalysts are significantly higher in concentrated phosphoric acid than those for more diluted solutions, being the apparent cause of adsorption of electrolyte on the electrode surface [7].

As it was stated by Miller in one of his latest publications [55], the cost of Nafion ${ }^{\circledR}$-based polymers calls for alternative membrane materials along with higher operating temperatures closer to $150{ }^{\circ} \mathrm{C}$. These membranes are required to improve kinetics and obtain higher conversion efficiencies in solid polymer electrolyte (SPE) electrolyzers and new solid electrolytes are needed.

Effective and affordable membranes are very important for the commercialisation of PEM water electrolyzers as it is both easier to manufacture and safer as neither acid nor electrolyte are in liquid phase.

\section{Construction materials for high temperature PEM water electrolysis (bipolar plates and current collectors)}

Elevated working temperatures involve increased demands for corrosion resistance of catalysts and current collectors, while the contact resistance in the GDL should remain reasonable.

High temperature PEM cell cannot be build from the same materials as a cell working below $100{ }^{\circ} \mathrm{C}$. Among new materials to be developed are polymer membranes, as commercial Nafion ${ }^{\circledR}$ membranes lose their conductivity at temperature above $100{ }^{\circ} \mathrm{C}$ due to membrane dehydration [5]. This means that different membranes should be used for this temperature range. It will be further discussed in Section 2. Elevated temperatures as well create more severe corrosion media for other components in the cell.

The anodic compartment of electrolyzer is expected to have stronger corrosive conditions than cathodic due to high positive polarization in combination with presence of evolving oxygen. This will be even more severe when the temperature is elevated. It is therefore an important task to choose materials which possess sufficient corrosion resistance. This demands further development of all materials from which electrolyzer cells are built.

One of the important components in PEM stack is a bipolar plate. Bipolar plate is a multifunctional and expensive part in a electrolysis stack as it collects and conduct current from cell to cell, permits an adequate gas flow, and the flow channels in the plate carry off produced gases, as well as providing most of the mechanical strength of the stack. In a typical 
PEM electrolysis stack, bipolar plates comprise most of the mass, and almost all the volume. Usually they also facilitate heat management in the system. These complex requirements make a task of finding proper materials difficult [12]. The highly oxidising acidic conditions in the oxygen electrode compartment pose a serious challenge to the materials used in these systems [19].

The most crucial demands for bipolar plate materials are resistance to spalling, dimensional stability and resistance to corrosion in electrolyte media under anodic/cathodic polarization. Numerous research projects have been devoted to bipolar plate materials in fuel cells $[6,25$, $32,37,50,71,72,76]$. However, the number of suitable materials for PEM electrolyzers is still limited because of high requirements for corrosion resistance at the oxygen electrode, where high overpotentials are combined with low $\mathrm{pH}$ media of electrolyte.

In Nafion ${ }^{\circledR}$-based systems, titanium is the most widely used bipolar plate material, which is ideal in terms of corrosion resistance and conductivity [17, 24, 41,67]. Porous sintered titanium powder commonly serves as a GDL material [22, 23].

The conductivity of Nafion ${ }^{\circledR}$ membranes decreases dramatically at temperatures above $100{ }^{\circ} \mathrm{C}$ (Section 2). Thus, PBI membranes doped with phosphoric acid are typically used in PEM fuel cells at elevated temperatures [24]. However, materials like steels corrode easily in phosphoric acid solutions and therefore it is important to study other alloys and materials for current collectors [9, 62]. Tantalum and nickel alloys show better corrosion resistance than stainless steels partly due to higher corrosion potentials and partly due to the formation of passive oxide layers on the metal surface [57,65]. Titanium generally has rather limited resistance to phosphoric acid [33]. Previous studies showed that titanium current collectors would considerably suffer from corrosion at temperatures above $80^{\circ} \mathrm{C}$ in concentrated phosphoric acid environments [34,59].

Different types of stainless steels can be used as bipolar plates, and they have advantages of being good heat and electricity conductors, can be machined easily (e.g. by stamping), are non-porous, and consequently very thin pieces are able to keep the reactant gases apart.

A possible alternative to stainless steel bipolar plates can be the use of nickel-based alloys [65]. Ni-based alloys are widely applied in process industry and energy production in nuclear power plants. When compared to conventional stainless steels, generally a higher degree of resistance against corrosion is observed for these materials. This can be explained partly by more noble corrosion potential of $\mathrm{Ni}$ and by different properties of the oxide films formed on Ni-based alloys [65]. Also, it has been proposed recently that nickel and stainless steel alloys can be used as a construction material in PEM water electolysers, but at temperatures no higher than $100{ }^{\circ} \mathrm{C}[34]$.

In order to simulate corrosion conditions at the anodic compartment of a PEM water electrolysis cell during half-cell experiments, it is necessary to choose a proper electrolyte. Investigating systems including membranes based on perfluorinated sulfonic acid, e.g. Nafion ${ }^{\circledR}, 0.5 \mathrm{M}$ sulphuric acid is commonly used as an electrolyte, simulating the electrolyzer cell conditions $[52,68]$. Similarly, $\mathrm{H}_{3} \mathrm{PO}_{4}$ can be used to model systems based on membranes doped with $\mathrm{H}_{3} \mathrm{PO}_{4}$. $85 \%$ solution of $\mathrm{H}_{3} \mathrm{PO}_{4}$ can be chosen to study the limiting case of corrosion, considering that in working electrolyzer systems the actual concentration of active acid at the electrode-electrolyte-water three-phase boundary would by much less than in this limiting case. 
In a highly oxidizing media such as the anodic compartment of high temperature steam electrolysis stack, it is essential to characterize the effect of different parameters on the behaviour of the protective oxide films. To date, no works have been addressed to the study of Ni-based alloys for use as bipolar plates in high temperature PEM steam electrolyzers.

In this work, metal alloys, namely austenitic stainless steels AISI 316L, AISI 321, AISI 347 and Ni-based alloys Hastelloy ${ }^{\circledR} \mathrm{C}-276$, Inconel ${ }^{\circledR} 625$, Incoloy ${ }^{\circledR} 825$, as well as titanium and tantalum were tested in terms of their corrosion resistance in the conditions, simulating those in the PEM electrolyzer systems, operating at temperatures above $100{ }^{\circ} \mathrm{C}$. Platinum and gold were also investigated for studying the potential window of concentrated $\mathrm{H}_{3} \mathrm{PO}_{4}$. All samples were subjected to anodic polarisation in $85 \%$ phosphoric acid electrolyte solution at $120^{\circ} \mathrm{C}$. The corrosion speed of metal alloys was investigated additionally for $30^{\circ} \mathrm{C}$ and $80^{\circ} \mathrm{C}$ to show the influence of temperature on corrosion resistance.

\subsubsection{Metal coatings and a CVD technique}

As the requirements to construction materials are quite severe and the price for materials which fulfil these requirements tends to be rather high, one of the approaches can be use of a coating on the less expensive and available material. If the technology is robust and affordable, the price of the materials can be significantly reduced, as expensive material use is restricted to the surface. Tantalum was shown to have superior resistance towards acidic solutions [39]. This is attributed to the formation of a thin $\mathrm{Ta}_{2} \mathrm{O}_{5}$ passivating film. As the cost of this material is rather high, its use is often limited to the coatings.

Cardarelli et. al showed that $\mathrm{IrO}_{2}$ electrodes, prepared on copper base material, which is coated with tantalum by molten salt electroplating present much better corrosion stability than coatings, made on pure titanium [11].

Chemical vapour deposition (CVD) process can be used for tantalum coatings preparation, where product is deposited on the surface of a substrate inside the reaction chamber. The most common process of chemical vapour deposition (CVD) coating is hydrogen reduction of a metal chloride [53].

In this work a commercial CVD "Tantaline" coating on stainless steel AISI 316L, provided by Tantaline A/S (Denmark) was tested for corrosion in high temperature PEM electrolyzer cell (HTPEMEC) environment [30].

\subsection{Assessment of materials for their corrosion stability}

\subsubsection{Steady state polarisation and corrosion studies}

Traditionally, the weight loss technique has been used to determine the corrosion rates of different materials $[9,48,49,57,64]$. It involves the periodic weight loss measurements after the defined time intervals having a sample immersed in an electrolyte. This technique is straightforward and does not require any knowledge of corrosion reactions that are occurring, however, prolonged test periods are needed (over 200h) for reasonable accuracy in this technique [18].

The electrochemical techniques potentially offer a faster way of determining corrosion rates, as nature of corrosion in electrolyte solutions is electrochemical. Therefore, generally 
considering corroding species of valence $n$, will give the following equation:

$$
\mathrm{M} \rightarrow \mathrm{M}^{n+}+\mathrm{ne}^{-}
$$

The Tafel equation 7 describes the current density as a function of the electrode potential and can be used for the study of corrosion speed and mechanisms. The rate of the uniform corrosion can be calculated through the exchange current density value directly to the mass loss rates or penetration rates (corrosion rate). It is made by means of the Tafel extrapolations [3].

$$
\begin{aligned}
& \frac{i}{i_{0}}=-e^{-\alpha f \eta} \Leftrightarrow-\ln \left(\frac{i}{i_{0}}\right)=-\alpha f \eta \Leftrightarrow \\
& \eta=\frac{1}{\alpha f} \ln \left(\frac{i}{i_{0}}\right) \Leftrightarrow \eta=\frac{1}{\alpha f}\left(\ln i-\ln i_{0}\right) \Leftrightarrow \\
& \eta=\frac{R T}{n F \alpha}\left(\ln i-\ln i_{0}\right)=\alpha-(1-x) \ln i
\end{aligned}
$$

The overpotential $\eta$ is plotted against the $\log i$ value through the Tafel plot (Figure 3 ). The intersection of two branches of the plot defines the corrosion current (corrosion current density $i_{\text {cor }}$ ), which is attributed to the main corrosion reaction taking place (equation 6 ). $i_{\text {cor }}$ equals to $i_{0}$ at $E_{\text {cor }}$ (equations 8-13). The values of the measured exchange current will show the maximum possible rate of corrosion in these conditions, as the effect of passivation is not taken into account.

$$
\begin{aligned}
& \text { for } E>>E_{\mathrm{cor},} i \simeq i_{a}=i_{0} \cdot \exp \left\{\frac{(1-\alpha) \cdot n \cdot F}{R T} \cdot\left(E-E_{\mathrm{cor}}\right)\right\} \\
& \text { for } E<<E_{\mathrm{cor},} i \simeq i_{c}=-i_{0} \cdot \exp \left\{\frac{-\alpha \cdot n \cdot F}{R T} \cdot\left(E-E_{\mathrm{cor}}\right)\right\} \\
& \ln i_{a}=\ln i_{0}+\frac{(1-\alpha) \cdot n \cdot F}{R T} \cdot\left(E-E_{\mathrm{cor}}\right) \\
& \ln -i_{c}=\ln i_{0}+\frac{-\alpha \cdot n \cdot F}{R T} \cdot\left(E-E_{\text {cor }}\right) \\
& \ln i_{a}=\ln -i_{c} \rightarrow E=E_{\mathrm{cor}} \\
& i_{a}\left(E_{\mathrm{cor}}\right)=i_{0}
\end{aligned}
$$

The corrosion potential ( $\left.E_{\text {cor }}\right)$ (Figure 3$)$ is another key parameter which gives an indication of how noble an electrode material is, or what is the minimum potential at which it starts to undergo corrosion.

Another alternative is to use the so-called "Cyclic Tafel voltammetry" technique [59, 74]. In this case after the forward polarisation, the scanning direction is reversed and the corrosion potential and current are measured for the "passivated" material.

The corrosion current $i_{\text {cor }}$ is found from the slope of the anodic polarisation curve, presented in the coordinates "electrode potential" vs. "log of the current density", as shown in Figure 3. The detailed ASTM technique description can be found elsewhere [3].

The assumption needs to be taken that the current distributes uniformly across the area of the electrode while using this technique. In this case, the current density equals:

$$
i_{\text {cor }}=\frac{I_{\text {cor }}}{A}
$$




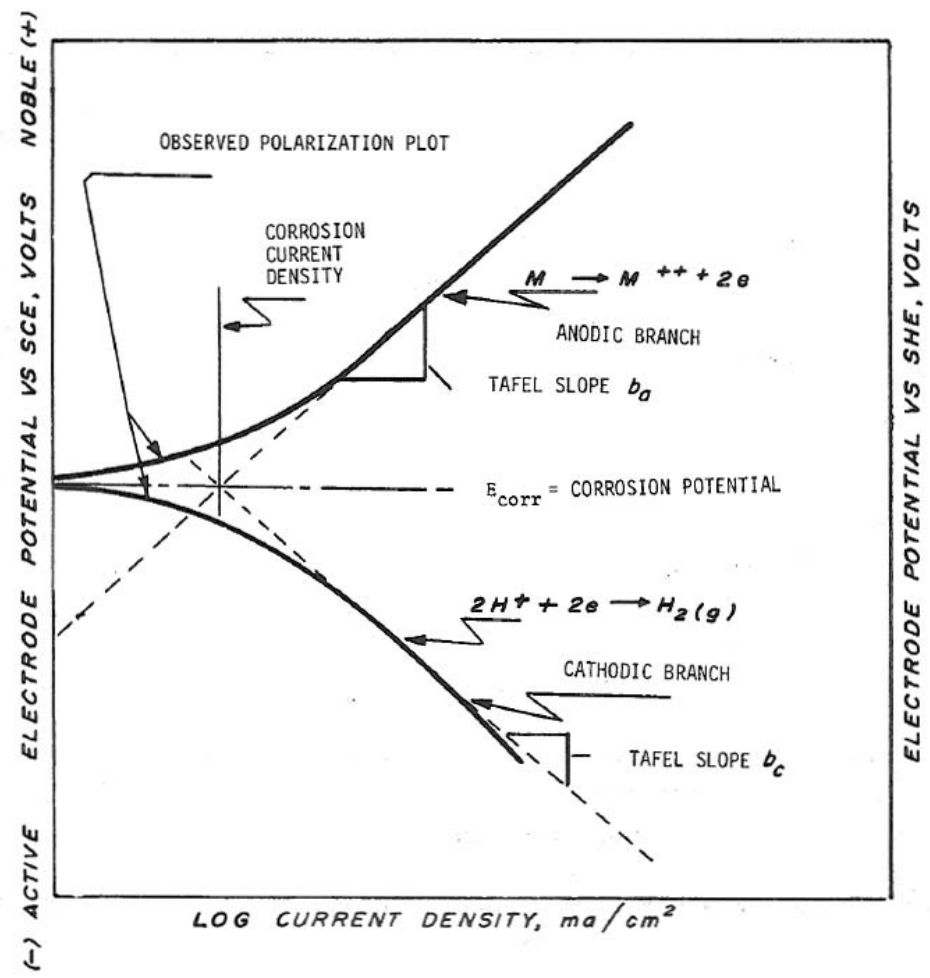

Figure 3. Hypothetical cathodic and anodic polarization diagram [3].

where $\mathrm{A}$ is the exposed specimen area, $\mathrm{cm}^{2}$

Further, the Faraday's Law is used for the calculation of the corrosion rate. For the penetration rate (corrosion rate $(\mathrm{CR})$ ) the derived from Faraday's Law equation is:

$$
C R=K_{1} \frac{i_{\text {cor }}}{\rho} E W
$$

- $\mathrm{CR}$ is given is $\mathrm{mm} /$ year

- $\mathrm{i}_{\mathrm{cor}}$ in $\mu \mathrm{A} / \mathrm{cm}^{2}$

- $K_{1}=3.27 \cdot 10^{-3}, \mathrm{~mm} \cdot \mathrm{g} / \mu \mathrm{A} \cdot \mathrm{cm} \cdot$ year

- $\rho$ is the density of material

- $E W$ is considered dimensionless in these calculations ans stands for the Equivalent Weight. For the pure elements the euivalent weight is given by:

$$
E W=W / n
$$

where

- $W=$ the atomic weight of the element, and

- $n=$ the number of electrons required to oxidize an atom of the element in the corrosion process, that is, the valence of the elevent. Details can be found in [2] 


\subsubsection{Materials and reactants for the experiment}

For preparation of the samples and the electrochemical experiments, the following substances were used:

- Demineralised water

- $\mathrm{H}_{3} \mathrm{PO}_{4} 85 \%$, Sigma Aldrich, puriss. p.a. (analytical purity)

- Ta plate electrode, Good Fellow Cambridge Ltd.

- Austenitic stainless steel plate (AISI 316L, AISI 321, AISI 347, annealed type of temper), by Good Fellow Cambridge Limited, England

- Ti foil, by Good Fellow Cambridge Limited (England)

- Hastelloy ${ }^{\circledR}$ C-276, Inconel ${ }^{\circledR} 625$ and Incoloy ${ }^{\circledR} 825$ plates, by T.GRAAE SpecialMetaller Aps (Denmark)

- CVD tantalum coated stainless steel AISI 316L was provided by Tantaline A/S, Denmark

- SiC abrasive paper, by Struers A/S (Denmark)

- Diamond powder polishing suspension, particle size less than $0.25 \mu \mathrm{m}$, by Struers A/S (Denmark)

- PolyFast phenolic hot mounting resin with carbon filler, provided by Struers A/S (Denmark)

\subsubsection{Materials and sample preparation}

Typical chemical compositions of stainless steels and nickel-based alloys investigated in this work are given in Table 1.

Chemical composition of alloys (elements, weight\%)

\begin{tabular}{|c|c|c|c|c|c|c|c|c|c|c|c|c|c|}
\hline Alloy type & $\mathrm{Ni}$ & $\mathrm{Co}$ & $\mathrm{Cr}$ & Mo & W & $\mathrm{Fe}$ & $\mathrm{Si}$ & $\mathrm{Mn}$ & $\mathrm{C}$ & $\mathrm{Al}$ & $\mathrm{Ti}$ & Other & $\mathrm{Nb}+\mathrm{Ta}$ \\
\hline AISI 347 & $9.0-13.0$ & - & $17-19$ & - & - & Bal. & 1.0 & 2.0 & 0.08 & - & - & - & 0.8 \\
\hline AISI 321 & $9.0-12.0$ & - & 17-19 & - & - & Bal. & 1.0 & 2.0 & 0.08 & - & $0.4-0.7$ & - & - \\
\hline AISI 316L & $10.0-13.0$ & - & $16.5-18.5$ & $2.0-2.5$ & - & Bal. & 1.0 & 2.0 & 0.03 & - & - & $\begin{array}{c}\mathrm{N} \\
\text { less } 0.11\end{array}$ & - \\
\hline Hastelloy ${ }^{\circledR}$ C-276 & 57 & 2.5 & 15.5 & 16.0 & 3.75 & 5.5 & 0.08 & 1.0 & 0.02 & - & - & $\begin{array}{c}\mathrm{V} \\
0.35\end{array}$ & - \\
\hline Inconel ${ }^{\circledR} 625$ & 62 & 1.0 & 21.5 & 9.0 & - & 5.0 & 0.5 & 0.5 & 0.1 & 0.4 & 0.4 & - & 3.5 \\
\hline Incoloy ${ }^{\circledR} 825$ & 44 & - & 21.5 & 3.0 & - & 27 & 0.3 & 1.0 & 0.05 & 0.1 & 1.0 & $\begin{array}{l}\mathrm{Cu} \\
2.0\end{array}$ & - \\
\hline
\end{tabular}

Table 1. Alloy chemical composition.

All specimens were cut into round plates of $15 \mathrm{~mm}$ in diameter. Afterwards the surfaces of all samples, apart from CVD tantalum coated SS316L, were manually ground prior to testing to eliminate any mill finish effects. Abrasive paper was used, followed by polishing with diamond powder. Finally, surfaces were degreased with acetone. 


\subsubsection{Characterisation}

A high temperature electrochemical cell (Figure 4) was specially designed for corrosion studies at elevated temperatures. The working electrode was designed to hold a disk sample, with a geometric area of opening ca. $0.2 \mathrm{~cm}^{2}$. A coil of platinum wire was used as a counter electrode to ensure a good polarization distribution. A calomel electrode was used as a reference electrode, connected to the system through a Luggin capillary. $85 \%$ phosphoric acid (analytical purity) was used as an electrolyte. Tests were performed at 30, 80 and $120^{\circ} \mathrm{C}$ at air atmosphere. In this work the electrochemical cyclic Tafel voltammetry technique is employed $[3,4,74]$. The experimental apparatus used for electrochemical studies was potentiostat model VersaSTAT 3 and VersaStudio software by Princeton Applied Research. After open-circuit potential was established, scanning was initiated with a scan rate of $1 \mathrm{mV} / \mathrm{s}$. The potential window was $1.5 \mathrm{~V}$, starting at a potential of $400 \mathrm{mV}$ less than the reference electrode potential and going up to $1.1 \mathrm{~V}$ more than the reference electrode potential. Reversed polarization was performed afterwards.

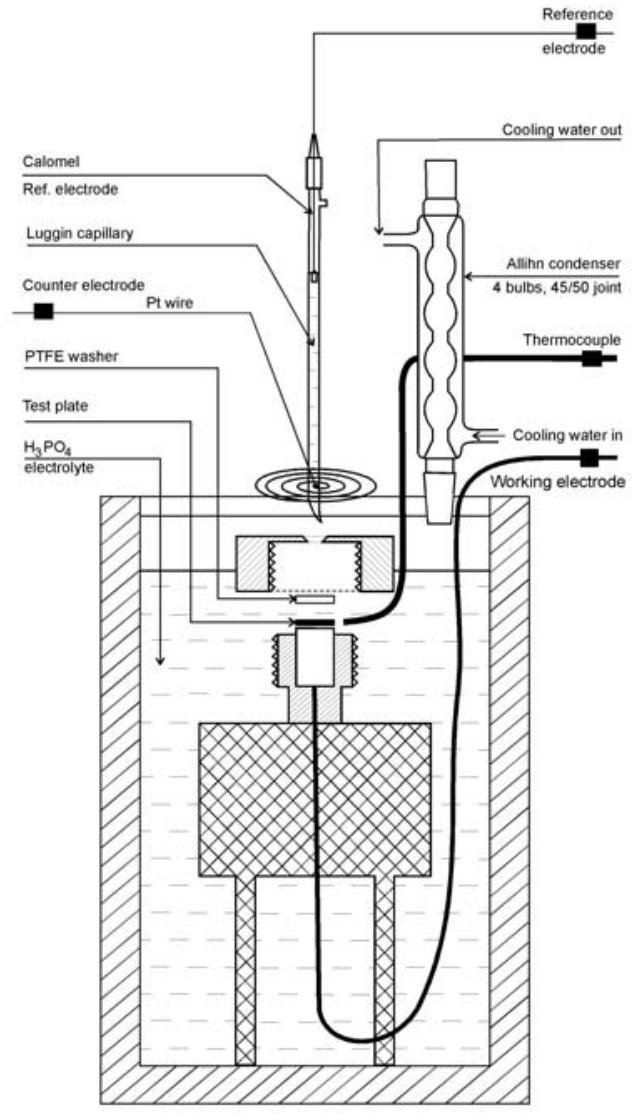

Figure 4. The electrochemical cell for corrosion testing in concentrated phosphoric acid. 
Cross-sections of the samples before and after voltametric measurements were studied using scanning electron microscopy (SEM) and energy dispersive X-ray spectroscopy (EDX). The cut was made for all the samples before and after immersion in $85 \% \mathrm{H}_{3} \mathrm{PO}_{4}$ at $120{ }^{\circ} \mathrm{C}$ for the time of electrochemical experiment. Duplicate plates were prepared for the cross-section investigation before the exposition. All samples were mounted in the hot mounting resin. SEM measurements were made with an JEOL JSM 5910 scanning electron microscope. The EDX-system used was INCA from Oxford Instrument (accelerating voltage $20.00 \mathrm{kV}$, working distance $10 \mathrm{~mm}$ ).

\subsubsection{Results and discussion}

Figure 5 represents the polarisation curves for platinum and gold foil, which show the electrochemical stability window for these materials in concentrated phosphoric acid at $120{ }^{\circ} \mathrm{C}$. It can be seen that platinum is a better catalyst for $\mathrm{O}^{2-}$ oxidation then gold (figure $5)$.

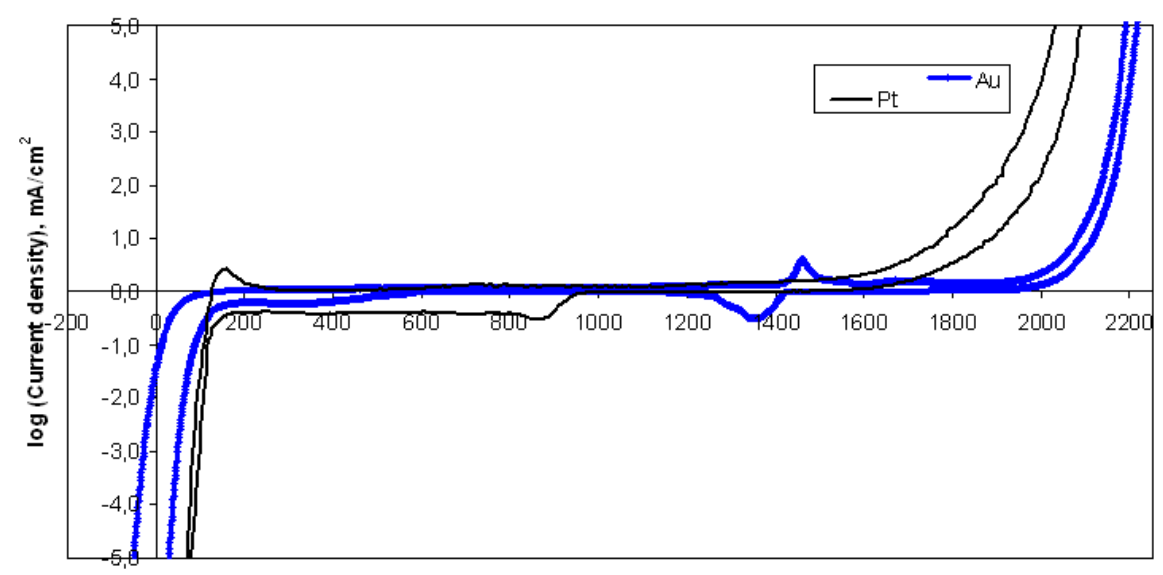

Potential, mV (vs. SHE)

Figure 5. Potential window for $\mathrm{Pt}$ and $\mathrm{Au}$ in $85 \% \mathrm{H}_{3} \mathrm{PO}_{4}, 120^{\circ} \mathrm{C}, 1 \mathrm{mV} / \mathrm{s}$ (vs. SHE).

The method of corrossion rate calculation, described in Section 3.1.1 was applied to all experiments. Figures 8-11 present Tafel plots for the materials tested, obtained at $80{ }^{\circ} \mathrm{C}$ and $120{ }^{\circ} \mathrm{C}$. Anodic exchange current density values were obtained from cyclic Tafel plots [3]. Corresponding corrosion currents and approximate corrosion rates were calculated as described in Section 3.1.1 and are presented in Table 2. Approximate CRs were calculated in terms of penetration rate, using the Faraday's Law [2].

For all studied materials there is a dramatic influence of temperature on corrosion rate, which grows with increasing temperature.

It can be seen from cyclic Tafel behaviour, that for all of the studied alloys corrosion is of a local type, i.e. pitting or intergranular Figures 8-11.

The analysis of the shape of cyclic Tafel voltammograms can give useful information about possible corrosion mechanisms [74]. Particularly, data related to pitting behaviour can be 


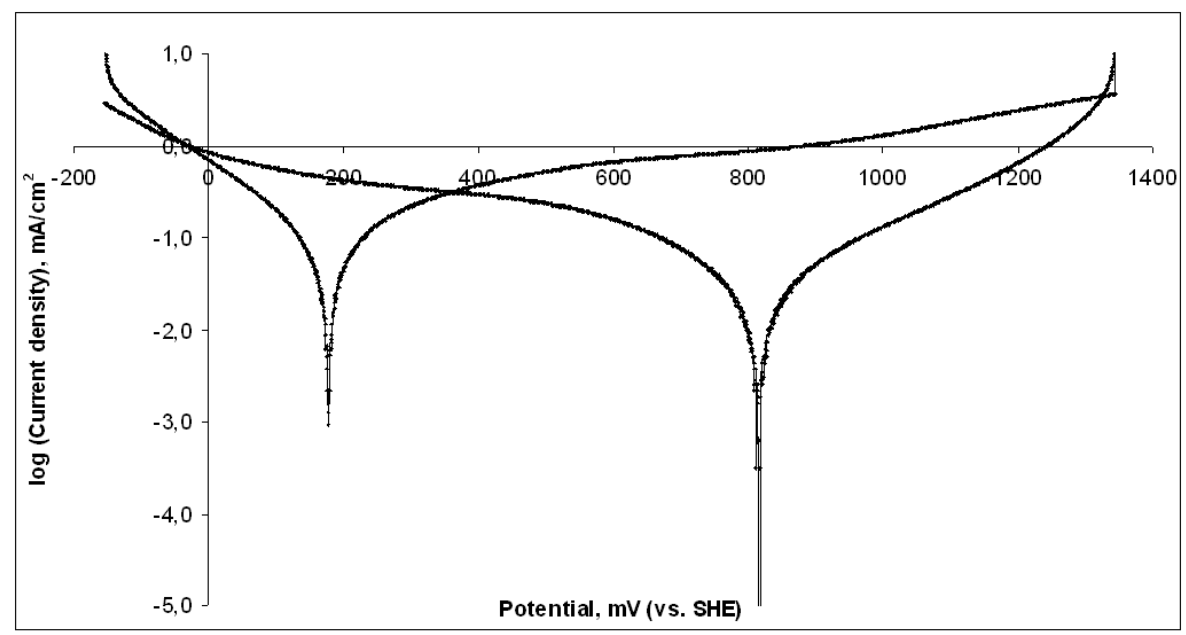

Figure 6. Tafel plot for AISI 321 in $85 \% \mathrm{H}_{3} \mathrm{PO}_{4}, 80^{\circ} \mathrm{C}, 1 \mathrm{mV} / \mathrm{s}$ (vs. SHE).

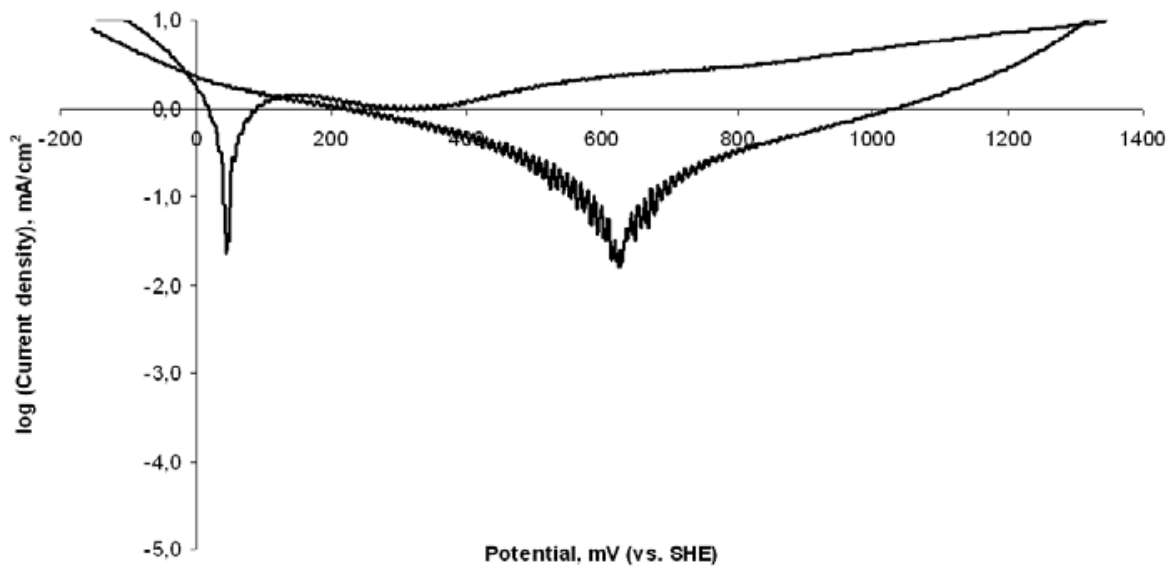

Figure 7. Tafel plot for AISI 321 in $85 \% \mathrm{H}_{3} \mathrm{PO}_{4}, 120^{\circ} \mathrm{C}, 1 \mathrm{mV} / \mathrm{s}$ (vs. SHE).

obtained using a method, proposed by Pourbaix [63]. In this case, the anodic polarisation scan is not terminated at high anodic potential, but is reduced at the same scan rate until reverse $\mathrm{E}_{\mathrm{cor}}$ is reached. Usually, this kind of graph is called "The pitting scan". Using this technique, it can be assumed that if any pits arise during forward anodic polarisation, any further initiation or propagation then ceases and the surface is covered with an oxide film.

For all materials investigated, besides titanium, the repassivation occurs easily. After changing the direction of polarisation in the highly anodic region, the reverse scan shows more positive corrosion potentials, and lower currents are recorded for the same values of potential. After the reverse voltametric curve crosses the forward one (closing the hysteresis loop), current continues to drop. In most cases, the loop is very small or does not exist, which 


\begin{tabular}{lccc}
\hline & \multicolumn{3}{c}{$i_{\text {corr }, ~} \mathrm{~mA}(\mathrm{CR}, \mathrm{mm} /$ year $)$} \\
\cline { 2 - 4 } Sample & \multicolumn{1}{c}{$30^{\circ} \mathrm{C}$} & $80^{\circ} \mathrm{C}$ & $120^{\circ} \mathrm{C}$ \\
\hline Stainless steel AISI 316L & $3.16 \times 10^{-3}(0,037)$ & $6.3 \times 10^{-2}(0.73)$ & $1.3 \times 10^{-1}(1.46)$ \\
Stainless steel AISI 321 & $1.26 \times 10^{-4}(<0.01)$ & $1.0 \times 10^{-2}(0.12)$ & $4.0 \times 10^{-2}(0.46)$ \\
Stainless steel AISI 347 & $3.02 \times 10^{-4}(<0.01)$ & $2.5 \times 10^{-2}(0.29)$ & $7.9 \times 10^{-2}(0.92)$ \\
${\text { Inconel }{ }^{\circledR} 625}^{1.58 \times 10^{-4}(<0.01)}$ & $5.3 \times 10^{-4}(<0.01)$ & $2.0 \times 10^{-2}(0.23)$ \\
Incoloy $^{\circledR} 825$ & $1.58 \times 10^{-4}(<0.01)$ & $2.0 \times 10^{-2}(0.23)$ & $3.2 \times 10^{-2}(0.37)$ \\
Hastelloy ${ }^{\circledR} \mathrm{C}-276$ & $1.95 \times 10^{-4}(<0.01)$ & $4.0 \times 10^{-3}(0.05)$ & $2.4 \times 10^{-2}(0.28)$ \\
Tantalum & & & $6.3 \times 10^{-5}(<0,001)$ \\
Titanium & & & $6.3(73,3)$ \\
\hline
\end{tabular}

Table 2. The comparison of corrosion currents (approximate CRs) of different materials at $\mathrm{T}=30,80$ and $120^{\circ} \mathrm{C}$.

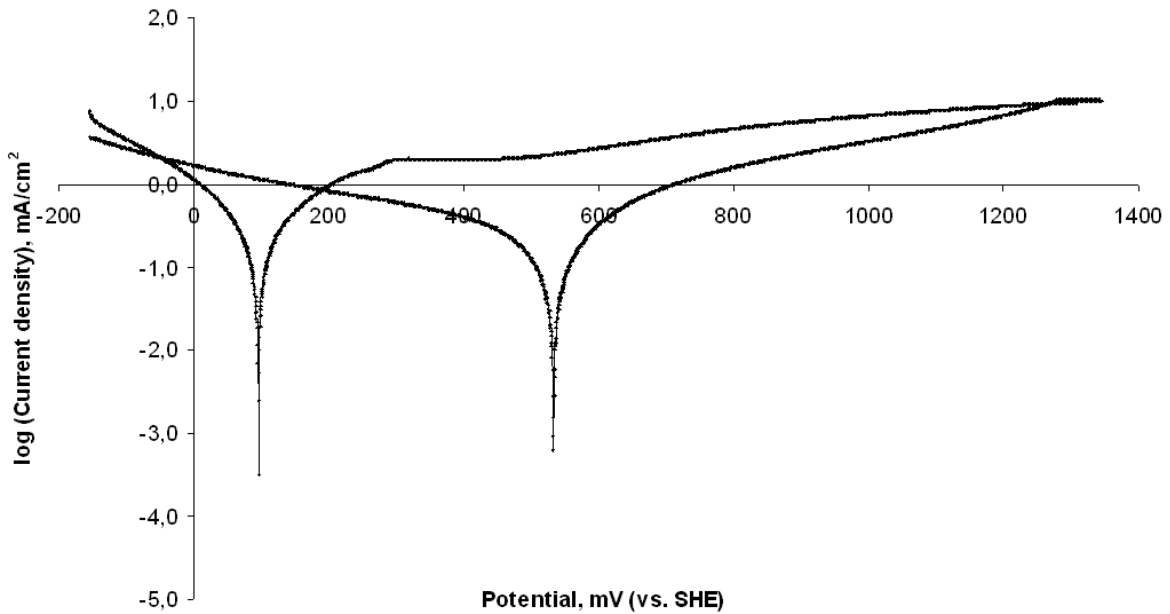

Figure 8. Tafel plot for AISI 316 in $85 \% \mathrm{H}_{3} \mathrm{PO}_{4}, 80^{\circ} \mathrm{C}, 1 \mathrm{mV} / \mathrm{s}$ (vs. SHE).

usually indicates high resistance to pitting type of corrosion. In other words, if any break in the passive layer occurs, it easily "heals" itself, preventing any further development of pits. Thus, it is expected that the pitting resistance is excellent for all tested alloys, because surface protection eliminates local active sites. For titanium the hysteresis loop is very wide, and lasts for almost the whole anodic part of the polarisation curve. Reverse scanning repeats forward with higher values of currents, indicating the absence of "healing" passivation.

In Table 3 the comparison of corrosion potentials for forward and back scans is given. In most cases, there is an obvious dependence between corrosion rate and $\mathrm{E}_{\text {cor }}$. For example, more positive value of $E_{\text {corr }}$ for AISI 321 stainless steel during reverse scan corresponds to the lowest corrosion speed of AISI 321 among other tested stainless steels.

Alloy AISI 321 exhibited the largest difference between forward (starting) and reverse corrosion potentials, as well as the most positive repassivation potential among the tested alloys at $120^{\circ} \mathrm{C}$. This corresponds to the lowest corrosion rate of AISI 321 among the stainless steels. 


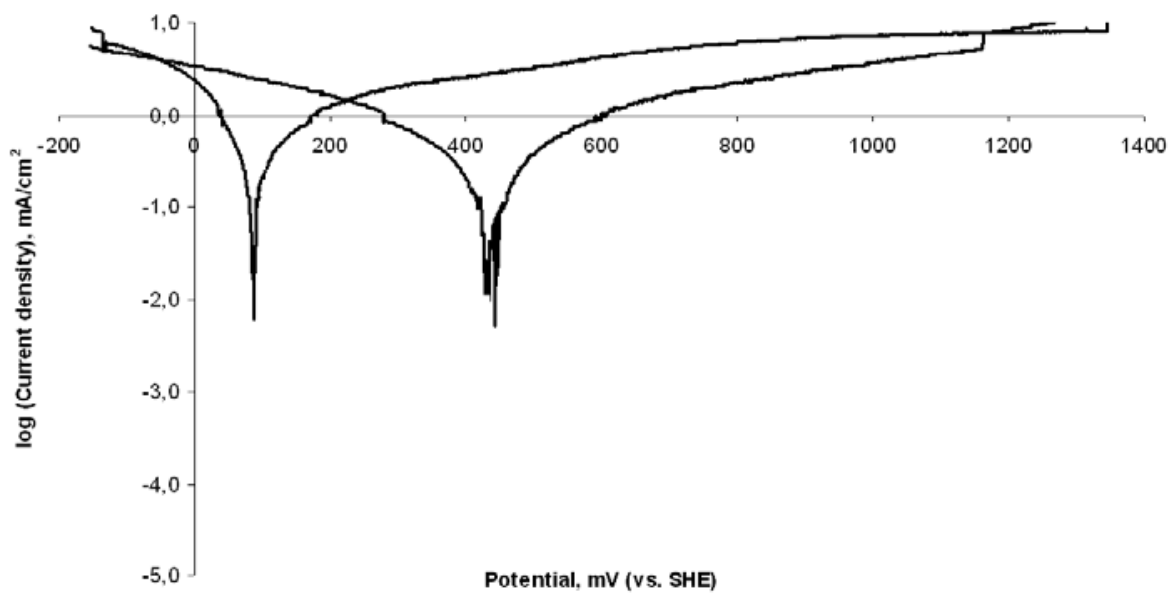

Figure 9. Tafel plot for AISI 316L in $85 \% \mathrm{H}_{3} \mathrm{PO}_{4}, 120^{\circ} \mathrm{C}, 1 \mathrm{mV} / \mathrm{s}$ (vs. SHE).

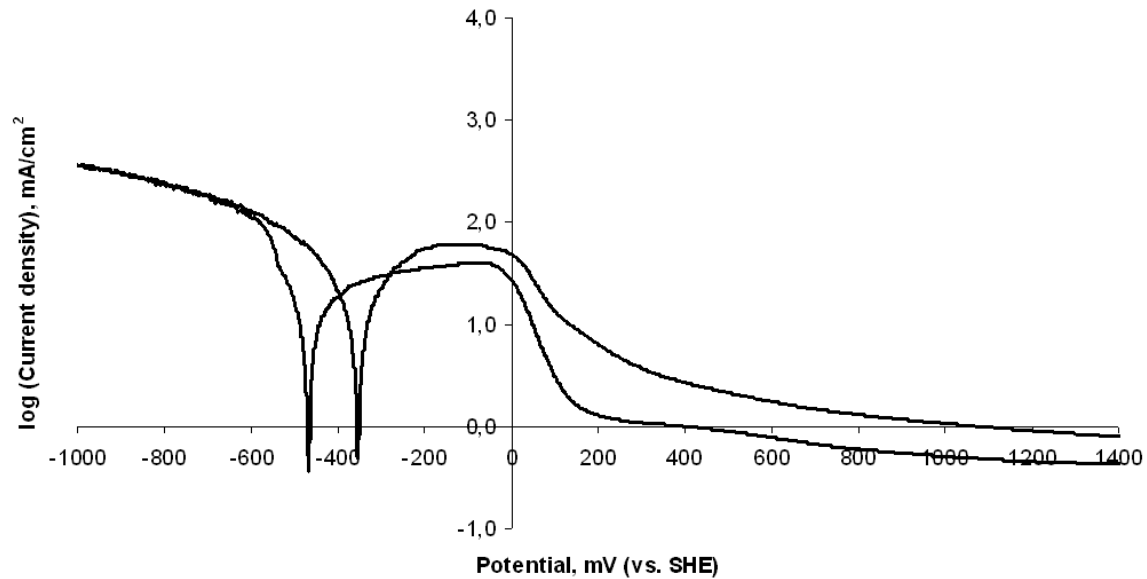

Figure 10. Tafel plot for titanium in $85 \% \mathrm{H}_{3} \mathrm{PO}_{4}, 120^{\circ} \mathrm{C}, 1 \mathrm{mV} / \mathrm{s}$ (vs. SHE).

Titanium showed the poorest corrosion resistance. At $120^{\circ} \mathrm{C}$ and open corrosion potential, the dissolution of titanium was observed visually, followed by intensive evolution of hydrogen gas. Under positive polarisation, it was partly passivated, but still the rates of dissolution were much higher than for austenitic stainless steels.

CVD tantalum coating on stainless steel showed an outstanding corrosion resistance, with the CRs being similar to earlier published data on this material [40]. The SEM image of the CVD-tantalum coated sample and the corresponding EDX spectra are shown in Figure 12 and Table 4 correspondingly. The coating appears to be homogeneous for the both sides of the plate, being around 5 and $50 \mu \mathrm{m}$ on the contrary sides of the sample. 


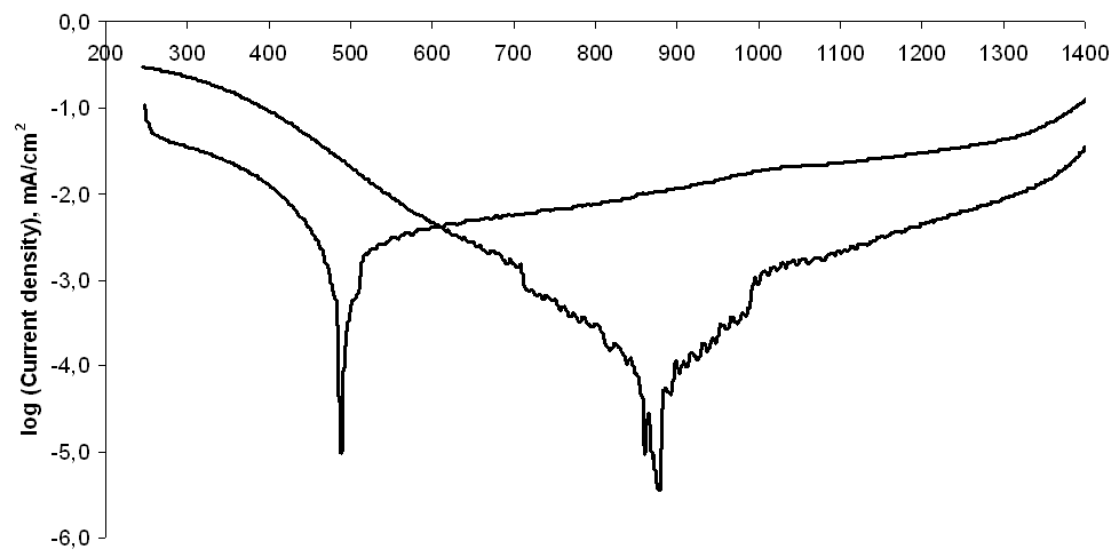

Potential, mV (vs. SHE)

Figure 11. Tafel plot for tantalum in $85 \% \mathrm{H}_{3} \mathrm{PO}_{4}, 120^{\circ} \mathrm{C}, 1 \mathrm{mV} / \mathrm{s}$ (vs. SHE).

\begin{tabular}{lcccc}
\hline & \multicolumn{3}{c}{$\mathrm{E}_{\mathrm{cor}}, \mathrm{mV}$ (vs. SHE) } \\
\hline Material & \multicolumn{2}{c}{$80{ }^{\circ} \mathrm{C}$} & \multicolumn{2}{c}{$120{ }^{\circ} \mathrm{C}$} \\
\cline { 2 - 5 } & forward reverse & forward reverse \\
Stainless steel AISI 316L & 100 & 530 & 80 & 430 \\
Stainless steel AISI 321 & 175 & 820 & 40 & 640 \\
Stainless steel AISI 347 & 320 & 770 & 320 & 500 \\
Inconel ${ }^{\circledR} 625$ & 125 & 635 & 90 & 490 \\
Incoloy ${ }^{\circledR} 825$ & 105 & 540 & 60 & 595 \\
Hastelloy ${ }^{\circledR} \mathrm{C}-276$ & 440 & 620 & 120 & 580 \\
Tantalum & & & 490 & 875 \\
Titanium & & & -465 & -357 \\
\hline
\end{tabular}

Table 3. Measured corrosion potentials for forward and back polarisation.

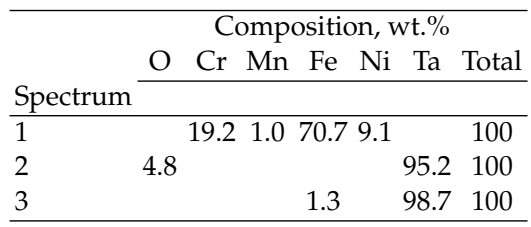

Table 4. EDX data for the CVD-tantalum coated stainless steel sample, in wt.\%.

The corrosion resistance at $120^{\circ} \mathrm{C}$ increases in the following sequence in our series: Titanium < AISI 316L < AISI $347<$ AISI $321<$ Incoloy ${ }^{\circledR} 825<$ Hastelloy ${ }^{\circledR}$ C $276<$ Inconel ${ }^{\circledR} 625<$ Tantalum It can be clearly noticed, that for alloys the corrosion stability grows with the increasing content of nickel in this media, as shown in Table 5. 


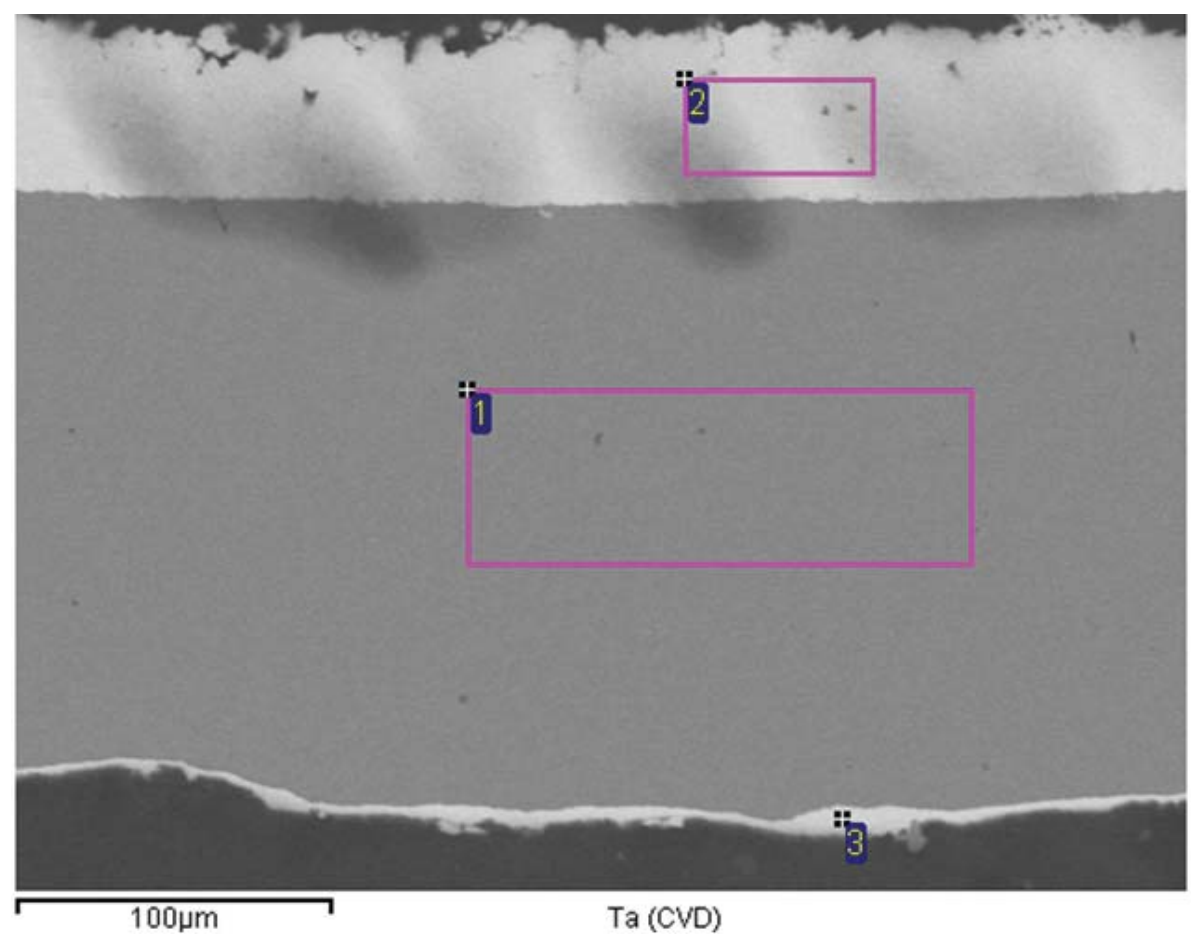

Figure 12. SEM image of the CVD-tantalum coated stainless steel sample. Numbers refer to EDX points and areas measured.

Generally, nickel based alloys show better corrosion stability than austenitic stainless steels in highly acidic media and elevated temperatures [77]. This tendency is also observed in our series.

Nickel's high degree of corrosion resistance is partly explained by the higher positive standard potential among the studied alloy compounds. Comparing with less resistant iron, nickel has $250 \mathrm{mV}$ more positive standard corrosion potential. But compared to pure nickel metal, nickel-chromium-iron-molybdenum alloys show considerably better resistance to corrosion in all inorganic acid solutions [65].

It can also be seen from Table 5, that titanium has a positive effect on the corrosion resistance of the alloys tested, even though its own resistance is much lower. This effect can be explained by the EDX data, obtained from AISI 321 and Inconel ${ }^{\circledR} 625$ before and after the electrochemical tests.

\begin{tabular}{lcccccc}
\hline Sample & AISI 347 & AISI 316L & AISI 321 & Inconel $l^{\circledR}$ 625 & Incoloy ${ }^{\circledR} 825$ & Hastelloy ${ }^{\circledR} \mathrm{C}-276$ \\
Ni content, wt.\% & $9-13$ & $10-13$ & $9-12$ & 62 & 44 & 57 \\
Ti content, wt.\% & - & - & $0.4-0.7$ & 0.4 & 1.0 & -
\end{tabular}

Table 5. The content of $\mathrm{Ni}$ and $\mathrm{Ti}$, in the tested alloys.

It is visible from Figures 13(a) (spectrum 3,4) and 13(b) (spectrum 2,4)and Tables 5(a) and 5(b) that before the corrosion test, $\mathrm{Ti}$ is not spread evenly on the surface of AISI 321, it is localized 
at definite points, unlike the other elements, distributed more homogeneously. It is safe to assume that points of Ti location are situated on intergranular boundaries. It follows from the data that the content of titanium in the intergranular region dropped after the electrochemical experiment, indicating that corrosion in AISI 321 develops along the intergranular boundaries in this media. Titanium tends to be distributed along these boundaries during the severe anodic attack, thus preventing the formation of chromium carbides in these areas, which could promote chromium concentration drop resulting in a loss of passivity in these regions.

(a)

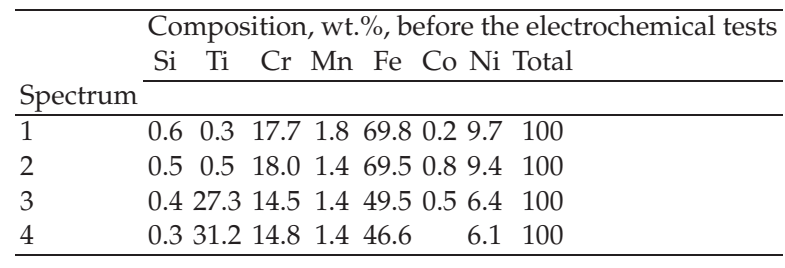

(b)

\begin{tabular}{lccccccccc}
\hline & \multicolumn{8}{c}{ Composition, wt.\%, after the electrochemical tests } \\
\cline { 3 - 8 } Spectrum & Si & Ti & Cr & Mn & Fe & Co Ni & Total \\
\cline { 2 - 8 } & 0.3 & 0.5 & 17.7 & 1.6 & 70.4 & 1.0 & 8.5 & 100 \\
2 & 0.1 & 29.2 & 15.3 & 1.5 & 48.5 & 0.3 & 5.2 & 100 \\
3 & 0.5 & 0.1 & 18.2 & 1.2 & 69.8 & 1.0 & 9.2 & 100 \\
4 & 1.2 & 9.0 & 17.5 & 0.9 & 62.4 & 0.6 & 8.4 & 100 \\
\hline
\end{tabular}

Table 6. EDX analysis data of AISI 321 before(a) and after(b) the electrochemical tests.

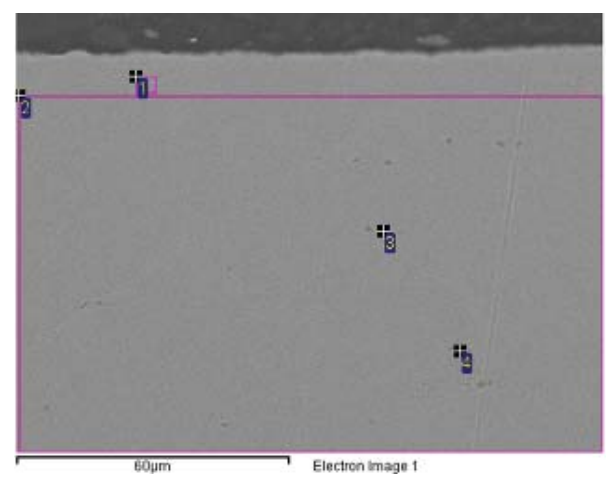

(a)

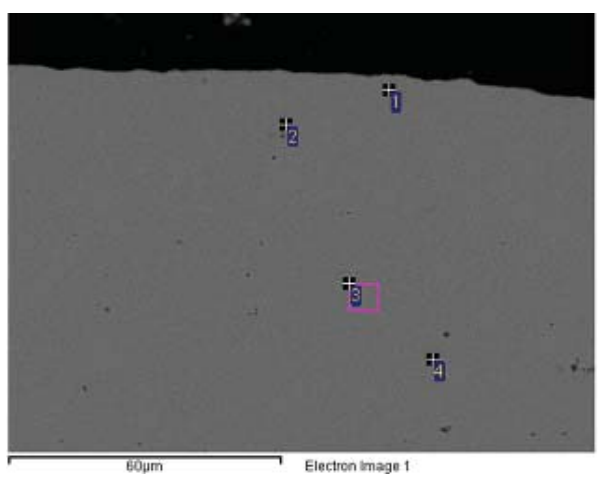

(b)

Figure 13. SEM of AISI 321 before(a) and after(b) the electrochemical tests. Numbers refer to EDX points and areas measured.

The same behaviour is observed for another alloy, containing titanium as an addition, protecting the material from intergranular corrosion. Figures 14(a) (spectrum 3,4), 14 (spectrum 1,3,5) and Tables 6(a) and 6(b) show SEM and EDX data for Inconel ${ }^{\circledR} 625$. The same 
tendency is even more significant for this alloy. The titanium is distributed irregularly and its content decreases after the corrosion experiment.

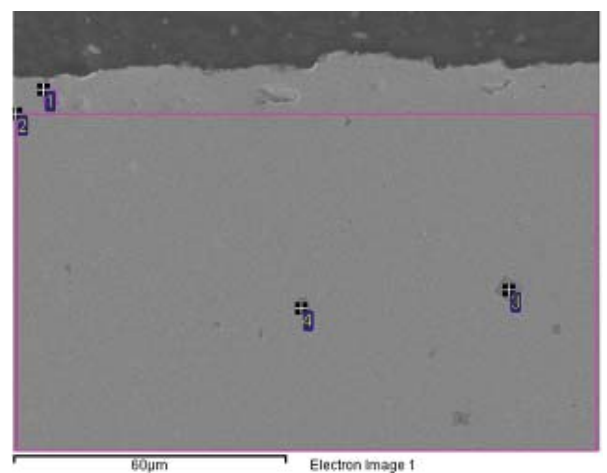

(a)

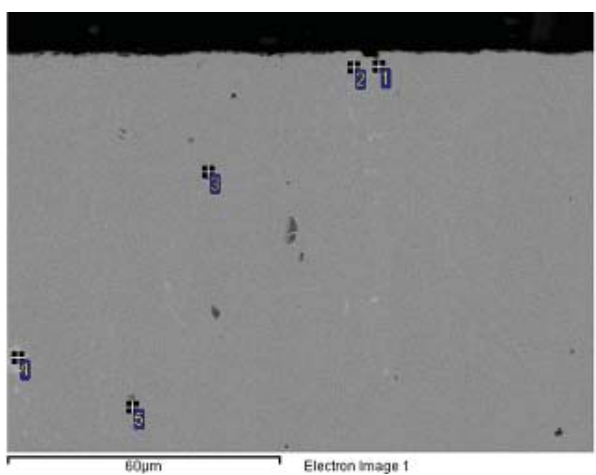

(b)

Figure 14. SEM of Inconel ${ }^{\circledR} 625$ before(a) and after(b) the electrochemical tests. Numbers refer to EDX points and areas measured.

(a)

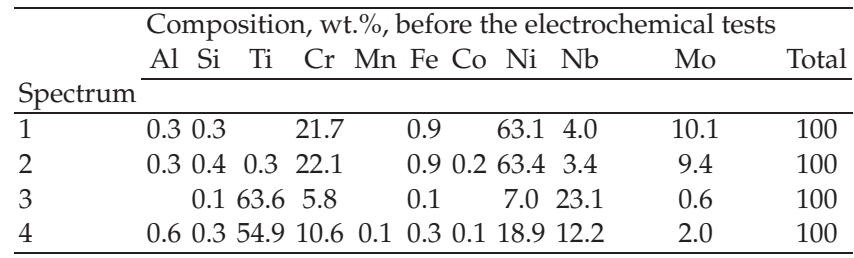

(b)

\begin{tabular}{|c|c|c|c|c|c|c|c|c|}
\hline & \multicolumn{8}{|c|}{ Composition, wt.\%, after the electrochemical tests } \\
\hline & Al Si Ti & $\mathrm{Cr}$ & $\mathrm{Mn}$ & $\mathrm{Fe} \mathrm{Co}$ & $\mathrm{Ni}$ & $\mathrm{Nb}$ & Mo & Total \\
\hline \multicolumn{9}{|c|}{ Spectrum } \\
\hline 1 & 0.50 .820 .5 & 13.7 & 0.3 & 0.4 & 34.9 & 21.4 & 7.9 & 100 \\
\hline 2 & 2.20 .1 & 15.8 & 0.5 & 0.5 & 40.1 & 14.0 & 27.0 & 100 \\
\hline 3 & 0.20 .148 .6 & 12.3 & 0.0 & 0.8 & 24.4 & 10.0 & 3.9 & 100 \\
\hline 4 & 0.32 .10 .1 & 13.7 & 0.7 & 0.10 .1 & 29.4 & 26.1 & 27.5 & 100 \\
\hline 5 & 0.143 .4 & 11.1 & & 0.40 .3 & 21.2 & 19.8 & 4.0 & 100 \\
\hline
\end{tabular}

Table 7. EDX analysis data of Inconel ${ }^{\circledR} 625$ before(a) and after(b) the electrochemical tests.

The discussion above proves the extremely important role of doping the investigated alloys with titanium in this media, thus protecting them from the most apparent intergranular type of corrosion.

Molybdenum is more soluble in nickel than in austenitic stainless steels, and higher levels of alloying are possible with a higher content of nickel. Therefore, the molybdenum content limit 
grows with nickel content and high contents of molybdenum are only possible in high nickel alloys [10].

Generally, the addition of molybdenum to stainless steels and alloys is used for enhanced corrosion resistance. For instance, the addition of even one or two percent of molybdenum to ferritic stainless steels significantly increases the corrosion resistance of these material.

Pure nickel-molybdenum alloys, namely alloy B-2, contain approximately $28 \%$ molybdenum and and about $1,7 \%$ iron. The very high molybdenum content gives excellent resistance to reducing acids, i.e. hydrochloric and sulphuric [20]. For sulphuric acid, this alloy shows good resistance, even at concentrations close to $90 \%$ and temperatures up to $120{ }^{\circ} \mathrm{C}$. Non-oxidant conditions, however, must certainly exist in this case. Either the presence of oxygen or aeration will significantly accelerate corrosion rate [77]. However, the role of molybdenum is not clearly noticed in this series.

\section{Conclusions}

The corrosion stability of the chosen stainless steels and nickel-based alloys is insufficient for these materials to be used in HTPEMECs. However, CVD-tantalum coating showed outstanding stability in the selected media. Therefore, such coatings on the bipolar plates and gas diffusion layers are recommended for long term tests of working HTPEMECs.

Tantalum coated AISI 316L stainless steel and Inconel ${ }^{\circledR} 625$ are the most suitable materials for bipolar plate in high temperature steam electrolyzers with $\mathrm{H}_{3} \mathrm{PO}_{4}$ doped membranes. It has also been found that small addition of titanium to the alloys increases the corrosion stability in this media. Among austenitic stainless steels, AISI 321 has the lowest corrosion rate.

Anodic passivation with decreased rate of dissolution was observed from the Tafel plots for all alloys and metals studied indicating the formation of a protective oxide layer. The best corrosion resistance was found for tantalum. The titanium content was found to be an important parameter in the performance of the steels. The accumulation of titanium on the intergranular boundaries was assumed to inhibit the growth of chromium carbides on these regions, preventing intergranular corrosion of the samples. However, pure titanium showed the poorest resistance to corrosion, accompanied by the lowest corrosion potentials in the series and highest corrosion currents. Therefore, these facts exclude it as a possible material for use in bipolar plates in high temperature PEM steam electrolyzers, which operate on membranes doped with phosphoric acid.

\section{Acknowledgements}

Authors would like to express their gratitude to the Center for renewable hydrogen cycling (HyCycle), Denmark, contract No. 2104-07-0041 and the WELTEMP project under EU Seventh Framework Programme (FP7), grant agreement No. 212903.

\section{Author details}

Aleksey Nikiforov, Erik Christensen, Irina Petrushina, Jens Oluf Jensen and Niels J. Bjerrum Proton Conductors Group, Department of Energy Conversion and Storage, Technical University of Denmark 


\section{List of Acronyms}

AISI American Iron and Steel Institute

ASTM american society for testing and materials

CR corrosion rate

CVD chemical vapour deposition

EDX energy dispersive X-ray spectroscopy

GDL gas diffusion layer

HTPEMEC high temperature PEM electrolyzer cell

HTPEMFC high temperature PEM fuel cell

MEA membrane electrode assembly

OEE oxygen evolution electrode

PBI Poly[2,2'-(m-phenylene)-5,5'-bibenzimidazole

PEM polymer electrolyte membrane

PTFE polytetrafluoroethylene

SEM scanning electron microscopy

SHE standard hydrogen electrode

SOEC solid oxide electrolyzer cell

SPE solid polymer electrolyte

URFC unitized regenerative fuel cells

\section{References}

[1] Andolfatto, F., Durand, R., Michas, A., Millet, P. \& Stevens, P. [1994]. Solid polymer electrolyte water electrolysis: electrocatalysis and long-term stability, International Journal of Hydrogen Energy 19(5): 421 - 427.

[2] Annual book of ASTM standarts 10.05, G 102-89 (Reapproved 1999), p. 446-452 [n.d.].

[3] Annual book of ASTM standarts 10.05, G3-89, p. $42-47$ [n.d.].

[4] Annual book of ASTM standarts 10.05, G5-94, p. 60-70 [n.d.].

[5] Antonucci, V., Di Blasi, A., Baglio, V., Ornelas, R., Matteucci, F., Ledesma-Garcia, J., Arriaga, L. G. \& Arico, A. S. [2008]. High temperature operation of a composite membrane-based solid polymer electrolyte water electrolyser, Electrochimica Acta 53(24): 7350-7356.

[6] Antunes, R. A., Oliveira, M. C. L., Ett, G. \& Ett, V. [2010]. Corrosion of metal bipolar plates for PEM fuel cells: A review, International Journal of Hydrogen Energy 35(8): 3632-3647.

[7] Appleby, A. \& Vandrunen, C. [1975]. The oxygen evolution reaction on rhodium and iridium electrodes in $85 \%$ orthophosphoric acid, Journal of Electroanalytical Chemistry 60(1): 101-108.

[8] Barbir, F. [2005]. PEM electrolysis for production of hydrogen from renewable energy sources, Solar Energy 78(5): 661-669.

[9] Benabdellah, M. \& Hammouti, B. [2005]. Corrosion behaviour of steel in concentrated phosphoric acid solutions, Applied Surface Science 252(5): 1657-1661. 
[10] Bil'chugov, Y. I., Makarova, N. L. \& Nazarov, A. A. [2001]. On limit of molybdenum content of pitting-corrosion-resistant austenitic steels, Protection of Metals 37(6): 597-601.

[11] Cardarelli, F., Taxil, P., Savall, A., Comninellis, C., Manoli, G. \& Leclerc, O. [1998]. Preparation of oxygen evolving electrodes with long service life under extreme conditions, Journal of Applied Electrochemistry 28(3): 245-250.

[12] Carl W. Hamann, Andrew Hamnelt, W. V. [1997]. Electrochemistry, second edn, Wiley-VHC.

[13] Chen, G., Bare, S. R. \& Mallouk, T. E. [2002]. Development of supported bifunctional electrocatalysts for unitized regenerative fuel cells, Journal of The Electrochemical Society 149(8): A1092-A1099.

[14] Chin, D. \& Chang, H. H. [1989]. On the conductivity of phosphoric acid electrolyte, Journal of Applied Electrochemistry 19(1): 95-99.

[15] Connolly, D., Longwood \& Gresham, W. [1966]. Fluorocarbon vinyl ether polymers.

[16] Daghetti, A., Lodi, G. \& Trasatti, S. [1983]. Interfacial properties of oxides used as anodes in the electrochemical technology, Materials Chemistry and Physics 8: 1-90.

[17] Di Blasi, A., D’Urso, C., Baglio, V., Antonucci, V., Arico', A. S., Ornelas, R., Matteucci, F., Orozco, G., Beltran, D., Meas, Y. \& Arriaga, L. G. [2009]. Preparation and evaluation of $\mathrm{RuO}_{2}-\mathrm{IrO}_{2}, \mathrm{IrO}_{2}-\mathrm{Pt}$ and $\mathrm{IrO}_{2}-\mathrm{Ta}_{2} \mathrm{O}_{5}$ catalysts for the oxygen evolution reaction in an SPE electrolyzer, Journal of Applied Electrochemistry 39(2): 191-196.

[18] Divakar, R., Seshadri, S. G. \& Srinivasan, M. [1989]. Electrochemical techniques for corrosion rate determination in ceramics, Journal of the American Ceramic Society 72(5): 780-784.

[19] Dutta, S. [1990]. Technology assessment of advanced electrolytic hydrogen production, International Journal of Hydrogen Energy 15(6): 379-386.

[20] et. al., A. [1989]. United states patent 4846885.

[21] Ghany, N. A. A., Kumagai, N., Meguro, S., Asami, K. \& Hashimoto, K. [2002]. Oxygen evolution anodes composed of anodically deposited mn-mo-fe oxides for seawater electrolysis, Electrochimica Acta 48(1): 21 - 28.

[22] Grigoriev, S., Millet, P., Korobtsev, S., Porembskiy, V., Pepic, M., Etievant, C., Puyenchet, C. \& Fateev, V. [2009]. Hydrogen safety aspects related to high-pressure polymer electrolyte membrane water electrolysis, International Journal of Hydrogen Energy 34(14): 5986-5991.

[23] Grigoriev, S., Millet, P., Volobuev, S. \& Fateev, V. [2009]. Optimization of porous current collectors for PEM water electrolysers, International Journal of Hydrogen Energy 34(11): 4968-4973.

[24] He, R., Li, Q., Xiao, G. \& Bjerrum, N. J. [2003]. Proton conductivity of phosphoric acid doped polybenzimidazole and its composites with inorganic proton conductors, Journal of Membrane Science 226(1-2): 169-184.

[25] Hermann, A., Chaudhuri, T. \& Spagnol, P. [2005]. Bipolar plates for PEM fuel cells: A review, International Journal of Hydrogen Energy 30(12): 1297-1302.

[26] http://hycycle.dk/ [2009]. Hycycle. center for renewable hydrogen cycling. URL: http://hycycle.dk/

[27] http://www.ginerinc.com/[n.d.]. URL: http://www.ginerinc.com/

[28] http://www.hydrogenics.com/ [n.d.]. URL: http://www.hydrogenics.com/ 
[29] http://www.protonenergy.com [n.d.].

URL: http://www.protonenergy.com

[30] http://www.tantaline.com/ [n.d.].

URL: http://www.tantaline.com/

[31] Hu, W., Cao, X., Wang, F. \& Zhang, Y. [1997]. A novel cathode for alkaline water electrolysis, International Journal of Hydrogen Energy 22(6): 621 - 623.

[32] Hung, Y., EL-Khatib, K. M. \& Tawfik, H. [2005]. Corrosion-resistant lightweight metallic bipolar plates for PEM fuel cells, Journal of Applied Electrochemistry 35(5): 445-447.

[33] I.Kreysa, G. \& Eckermann, R. [1993]. DECHEMA corrosion handbook: corrosive agents and their interaction with materials, Vol. 12. Chlorinated hydrocarbons-chloroethanes, phosphoric acid, VCH Verlagsgesellschaft, Weinheim (Germany) and VCH Publishers, New York, NY (USA).

[34] International patent application, 03.01.2008, WO 2008/002150 A1, PCT/NO2007/000235 [03.01.2008].

[35] Jensen, J., Bandur, V., Bjerrum, N., Højgaard, S., Ebbesen, S. \& Mogensen, M. [2008]. Pre-investigation of water electrolysis, Technical report.

URL: $h$ ttp://130.226.56.153/rispubl/NEI/NEI-DK-5057.pdf

[36] Jensen, J. O., Li, Q. F., Pan, C., Vestbo, A. P., Mortensen, K., Petersen, H. N., Sorensen, C. L., Clausen, T. N., Schramm, J. \& Bjerrum, N. J. [2007]. High temperature PEMFC and the possible utilization of the excess heat for fuel processing, International Journal of Hydrogen Energy 32(10-11): 1567-1571.

[37] Joseph, S., McClure, J. C., Chianelli, R., Pich, P. \& Sebastian, P. J. [2005]. Conducting polymer-coated stainless steel bipolar plates for proton exchange membrane fuel cells (PEMFC), International Journal of Hydrogen Energy 30(12): 1339-1344.

[38] Jung, H. Y., Park, S., Ganesan, P. \& Popov, B. N. [2008]. Electrochemical studies of unsupported PtIr electrocatalyst as bifunctional oxygen electrode in unitized regenerative fuel cell (urfc), Proton Exchange Membrane Fuel Cells 8, Pts 1 and 2 16(2): 1117-1121.

[39] Keijzer, M., Hemmes, K., VanDerPut, P. J. J. M., DeWit, J. H. W. \& Schoonman, J. [1997]. A search for suitable coating materials on separator plates for molten carbonate fuel cells, Corrosion Science 39(3): 483-494.

[40] Kouřil, M., Christensen, E., Eriksen, S. \& Gillesberg, B. [2011]. Corrosion rate of construction materials in hot phosphoric acid with the contribution of anodic polarization, Materials and Corrosion .

[41] Labou, D., Slavcheva, E., Schnakenberg, U. \& Neophytides, S. [2008]. Performance of laboratory polymer electrolyte membrane hydrogen generator with sputtered iridium oxide anode, Journal of Power Sources 185(2): 1073-1078.

[42] Lage, L. G., Delgado, P. G. \& Kawano, Y. [2004]. Thermal stability and decomposition of Nafion ${ }^{\circledR}$ membranes with different cations using high-resolution thermogravimetry, Journal of Thermal Analysis and Calorimetry 75(2): 521-530.

[43] Lessing, P. A. [2007]. Materials for hydrogen generation via water electrolysis, Journal of Materials Science 42(10): 3477-3487.

[44] Li, Q. F., He, R. H., Jensen, J. O. \& Bjerrum, N. J. [2003]. Approaches and recent development of polymer electrolyte membranes for fuel cells operating above 100 degrees C, Chemistry of Materials 15(26): 4896-4915. 
[45] Li, Q., Jensen, J. O., Savinell, R. F. \& Bjerrum, N. J. [2009]. High temperature proton exchange membranes based on polybenzimidazoles for fuel cells, Progress in Polymer Science 34(5): 449-477.

[46] Linkous, C. [1993]. Development of solid polymer electrolytes for water electrolysis at intermediate temperatures, International Journal of Hydrogen Energy 18(8): 641-646.

[47] Linkous, C. A., Anderson, H. R., Kopitzke, R. W. \& Nelson, G. L. [1998]. Development of new proton exchange membrane electrolytes for water electrolysis at higher temperatures, International Journal of Hydrogen Energy 23(7): 525-529.

[48] Lu, J.-s. [2009]. Corrosion of titanium in phosphoric acid at $250{ }^{\circ} \mathrm{C}$, Transactions of Nonferrous Metals Society of China 19: 552-556.

[49] Lukashenko, T. A. \& Tikhonov, K. I. [1998]. Corrosion resistance of a series of group IV-VI transition metal carbides and nitrides in concentrated solutions of sulfuric and phosphoric acids., Zhurnal Prikladnoi Khimii (Sankt-Peterburg) 71(12): 2017-2020.

[50] Makkus, R. C., Janssen, A. H., de Bruijn, F. A. \& Mallant, R. K. [2000]. Use of stainless steel for cost competitive bipolar plates in the SPFC, Journal of Power Sources 86(1-2): 274-282.

[51] Marshall, A., Børresen, B., Hagen, G., Tsypkin, M. \& Tunold, R. [2006]. Electrochemical characterisation of $\operatorname{Ir}_{x} \mathrm{Sn}_{1-x} \mathrm{O}_{2}$ powders as oxygen evolution electrocatalysts, Electrochimica Acta 51:3161-3167.

[52] Marshall, A., Børresen, B., Hagen, G., Tsypkin, M. \& Tunold, R. [2007]. Hydrogen production by advanced proton exchange membrane (PEM) water electrolysers-reduced energy consumption by improved electrocatalysis, Energy 32: 431-436.

[53] M.Bengisu [1963]. Engineering Ceramics, Springer-Verlag Berlin Heidelberg 2001.

[54] McElroy, J. F. [1994]. Recent advances in SPE ${ }^{\circledR}$ water electrolyzer, Journal of Power Sources 47(3): 369-375. Proceedings of the Fourth Space Electrochemical Research and Technology Conference.

[55] Millet, P., Mbemba, N., Grigoriev, S., Fateev, V., Aukauloo, A. \& Etiévant, C. [2011]. Electrochemical performances of PEM water electrolysis cells and perspectives, International Journal of Hydrogen Energy 36: 4134-4142.

[56] Millet, P., Ngameni, R. \& Grigoriev, S. [2009]. PEM water electrolyszers: From electrocatalysis to stack development, International Journal of Hydrogen Energy 35: 5043 -5052 .

[57] Mitsuhashi, A., Asami, K., Kawashima, A. \& Hashimoto, K. [1987]. The corrosion behavior of amorphous nickel base alloys in a hot concentrated phosphoric acid, Corrosion Science 27(9): 957-970.

[58] Ni, M., Leung, M. \& Leung, D. [2007]. Energy and exergy analysis of hydrogen production by solid oxide steam electrolyzer plant, International Journal of Hydrogen Energy 32(18): 4648-4660.

[59] Nikiforov, A., Petrushina, I., Christensen, E., Tomás-García, A. L. \& Bjerrum, N. [2011]. Corrosion behaviour of construction materials for high temperature steam electrolysers, International Journal of Hydrogen Energy 36(1): 111-119.

[60] Oberlin R, F. M. [1986]. Status of the membral process for water electrolysis, Hydrogen energy progress VI, proceedings of the sixth world hydrogen energy conference, Oxford: Pergamon Press pp. 333-40.

[61] Oi, T. \& Sakaki, Y. [2004]. Optimum hydrogen generation capacity and current density of the pem-type water electrolyzer operated only during the off-peak period of electricity demand, Journal of Power Sources 129(2): 229 - 237. 
[62] Onoro, J. [2009]. Corrosion fatigue behaviour of 317LN austenitic stainless steel in phosphoric acid, International Journal of Pressure Vessels and Piping 86(10): 656-660.

[63] Pourbaix, M., Klimzack-Mathieiu, L., Mertens, C., Meunier, J., Vanleugenhaghe, C., de Munck, L., Laureys, J., Neelemans, L. \& Warzee, M. [1963]. Potentiokinetic and corrosimetric investigations of the corrosion behaviour of alloy steels, Corrosion Science 3(4): 239-259.

[64] Robin, A. \& Rosa, J. L. [2000]. Corrosion behavior of niobium, tantalum and their alloys in hot hydrochloric and phosphoric acid solutions, International Journal of Refractory Metals and Hard Materials 18: 13-21.

[65] Rockel, M. [1998]. Corrosion behaviour of nickel alloys and high-alloy stainless steel, Nickel Alloys, Marcel Dekker Inc, New York.

[66] Shin, Y., Park, W., Chang, J. \& Park, J. [2007]. Evaluation of the high temperature electrolysis of steam to produce hydrogen, International Journal of Hydrogen Energy 32(10-11): 1486-1491.

[67] Song, S. D., Zhang, H. M., Ma, X. P., Shao, Z. G., Zhang, Y. N. \& Yi, B. L. [2006]. Bifunctional oxygen electrode with corrosion-resistive gas diffusion layer for unitized regenerative fuel cell, Electrochemistry Communications 8(3): 399-405. Electrochemistry Communications.

[68] Song, S., Zhang, H., Ma, X., Shao, Z., Baker, R. T. \& Yi, B. [2008]. Electrochemical investigation of electrocatalysts for the oxygen evolution reaction in PEM water electrolyzers, International Journal of Hydrogen Energy 33: 4955-4961.

[69] Suffredini, H. B., Cerne, J. L., Crnkovic, F. C., Machado, S. A. S. \& Avaca, L. A. [2000]. Recent developments in electrode materials for water electrolysis, International Journal of Hydrogen Energy 25(5): 415-423.

[70] Swette, L. L., LaConti, A. B. \& McCatty, S. A. [1994]. Proton-exchange membrane regenerative fuel cells, Journal of Power Sources 47(3): 343-351.

[71] Tawfik, H., Hung, Y. \& Mahajan, D. [2007]. Metal bipolar plates for PEM fuel cell-A review, Journal of Power Sources 163(2): 755-767.

[72] Tian, R. J., Sun, J. C. \& Wang, L. [2006]. Plasma-nitrided austenitic stainless steel 316L as bipolar plate for PEMFC, International Journal of Hydrogen Energy 31(13): 1874-1878.

[73] Trasatti, S. [1980]. Electrodes of conductive metallic oxides, Studies in physical and theoretical chemistry, Elsevier, 335 Jan van Galenstraat P.O. Box 211, 1000 AE Amsterdam, The Netherlands.

[74] Trethewey, K. R. \& Chamberlain, J. [1988]. Corrosion, Longman Group UK Limited.

[75] Turner, J., Sverdrup, G., Mann, M. K., Maness, P., Kroposki, B., Ghirardi, M., Evans, R. J. \& Blake, D. [2008]. Renewable hydrogen production, International Journal of Energy Research 32(5): 379-407.

[76] Wang, Y. \& Northwood, D. O. [2007]. An investigation of the electrochemical properties of PVD TiN-coated SS410 in simulated PEM fuel cell environments, International Journal of Hydrogen Energy 32(7): 895-902.

[77] W.Z.Friend [1980]. Corrosion of Nickel and Nickel-Base Alloys, J.Wiley\&Sons, New York-Chichester-Brisbane-Toronto.

[78] Yamaguchi, M., Okisawa, K. \& Nakanori, T. [1997]. Development of high performance solid polymer electrolyte water electrolyzer in WE-NET, Proceedings of the Intersociety Energy Conversion Engineering Conference 3-4: 1958-1961. 
[79] Zhang, Y., Zhang, H., Ma, Y., Cheng, J., Zhong, H., Song, S. \& Ma, H. [2009]. A novel bifunctional electrocatalyst for unitized regenerative fuel cell, Journal of Power Sources 195: 142-145. 